\title{
Bioinformatics analysis of Rab GDP dissociation inhibitor beta and its expression in non-small cell lung cancer
}

Zongjuan Ming ${ }^{1}$, Chunli Guo ${ }^{2}$, Meihua Jiang ${ }^{1}$, Wei Li ${ }^{1}$, Yuping Zhang ${ }^{1}$, Na Fan ${ }^{1}$, Yujie Zhong ${ }^{1}$, Xia Meng ${ }^{1}$ and Shuanying Yang ${ }^{1 *}$

\begin{abstract}
Background: Lung cancer has been considered as one of the most important causes of cancer-related mortality worldwide. To predict lung cancer, researchers identified several molecular markers. However, many underlying markers of lung cancer remain unclear. One of these markers is Rab GDP dissociation inhibitor beta (GDIß), which is related to tumorigenicity, development and invasion. This study was designed to analyze the biological characteristics of Rab GDI $\beta$ and to detect the mRNA and protein expressions of Rab GDI $\beta$ in lung cancer cells; this study also aimed to investigate the functions of this protein in lung cancer.
\end{abstract}

Method: Using online software from the websites of NCBI, ProtParam and so on, we analyzed the biological characteristics of Rab GDIB. RT-PCR was performed to detect gene expressions in A549 and 16HBE cell lines and immunohistochemistry (IHC) staining was conducted to detect Rab GDI $\beta$ protein expression in 57 cases of human lung cancer tissues and 19 cases of normal lung tissues. The association of protein expression with patient clinical and pathological characteristics was assessed in each dataset.

Results: Bioinformatic analysis on Rab GDI $\beta$ : The mRNA of human Rab GDI $\beta$ contains two transcript variants; the common structural elements of the two proteins are mainly a-helix, random coil, $\beta$-turn and extended strand. Three and four transmembrane domains could be found in the entire polypeptide chain of protein variants 1 and 2, respectively; both transcript variants are hydrophilic and soluble proteins. The RT-PCR result: The mRNA expression of Rab GDI $\beta$ was down-regulation in A549 cells compared with that in 16HBE cells. The IHC result: The protein expression of Rab GDI $\beta$ in lung cancer cells was significantly lower than that in normal lung tissues $(P<0.05)$ but was not correlated with patients' age, gender, tumor size, pathological type, differentiation, lymph node metastasis, distant metastasis and TNM stage.

Conclusion: The expression of Rab GDI $\beta$ was low in non-small cell lung cancer (NSCLC). Hence, Rab GDI $\beta$ may be a tumor suppressor and could function as an indicator of tumorigenesis in NSCLC; nevertheless, this result should be further studied.

Virtual Slides: The virtual slide(s) for this article can be found here: http://www.diagnosticpathology.diagnomx. eu/vs/13000_2014_201

Keywords: Rab GDIß, NSCLC, Bioinformatics, Expression

\footnotetext{
*Correspondence: yangshuanying66@163.com

${ }^{1}$ Department of Respiratory Medicine, the Second Affiliated Hospital of Xi'an Jiaotong University, Xi'an 710004, China

Full list of author information is available at the end of the article
} 


\section{Background}

Lung cancer has been considered as one of the most common malignancies and yields the lowest survival rate among other cancers [1]. Non-small cell lung cancer (NSCLC) accounts for more than $80 \%$ of all lung cancers. Mortality related to this malignant disease has increased by $465 \%$ during the last 30 years in People's Republic of China [2]. Even those NSCLC patients have received standard treatments, including surgical resection, traditional chemotherapy, radiation therapy and molecular targeted therapy, the five-year survival rate of NSCLC is still lower than 15\% [3-5]. It has long been acknowledged that the aggressive nature of lung cancer is closely related to the activation of oncogenes and the inactivation of tumor suppressor genes [6-8]. However, numerous molecular alterations are involved in lung cancer development [9]; cancer initiation, progression and metastasis also remain poorly understood. Thus far, we still lack markers that can be used in early detection and targeted therapy. Therefore, novel cancer-specific molecular targets and signalling pathways should be developed to establish new therapeutic strategies against this devastating malignancy and to improve patient survival.

In our previous study on mitochondria proteomics, different proteins containing Rab GDP dissociation inhibitor beta $(\mathrm{GDI} \beta)$ were screened and identified [10]. Rab GDI $\beta$ is a member of the GDP dissociation inhibitor family that controls the recycling of Rab GTPases involved in membrane trafficking [11,12]. Rab GTPases, one of the Ras superfamily members of monomeric GTPases, are small $\mathrm{G}$ proteins. In recent years, a new function of Rab proteins has been observed in the control of tumor progression. Evidence [13-19] has further shown that Rab proteins are necessary to facilitate cancer cell adhesion and migration. As a Rab protein control factor, Rab GDI $\beta$ is also involved in the development of multiple tumors. Rab GDI $\beta$ controls the access of GTPases to regulatory guanine nucleotide exchange factors and GTPase-activating proteins [20]; Rab GDI $\beta$ may also function in tumor cell apoptosis [21]. Wang et al. [22] discovered that Rab GDI $\beta$ was significantly up-regulated in the highly metastatic gallbladder carcinoma cells GBC-SD18H compared with the poorly metastatic GBC-SD18L cell line. Proteomic analysis results have also shown that Rab GDI $\beta$ expressions in gastric cancer [23] and ovarian cancer [24] were aberrant compared with those in normal tissues. Therefore, Rab GDI $\beta$ possibly participates in cancer initiation and progression.

However, whether Rab GDI $\beta$ is involved in the development of NSCLC is yet to be reported. In the present study, the biological characteristics of Rab GDI $\beta$ were analyzed. RT-PCR was conducted to detect the mRNA expression levels of Rab GDI $\beta$ in lung adenocarcinoma cell line A549 and normal human bronchial epithelial cell line 16HBE.
Immunohistochemistry (IHC) was performed to quantify the protein expression of Rab GDI $\beta$ in lung cancer tissues. Then the relationship between this expression and clinicopathological factors was examined. These studies may provide important references related to the potential function of Rab GDI $\beta$ in human NSCLC progression.

\section{Methods \\ Bioinformatics analysis}

Biological characteristics, including physicochemical properties, homology, secondary structure, transmembrane domain, functional domain, subcellular localisation, three-dimensional (3D) structure, phosphorylation sites and functions of Rab GDI $\beta$, were analyzed using online software from the websites of NCBI, ProtParam, SOPMA, TMpred, SMART, ProtScale, SOSUI, PSORT II, SwissMODEL Repository and so on. The gene and protein interaction networks of Rab GDI $\beta$ were established on the basis of the platform of GeneMANIA and STRING9.0.

\section{Cell culture}

Human lung adenocarcinoma cells A549 were obtained from the central laboratory of Xi'an Jiaotong University and grown in a complete medium containing RPMI 1640 supplemented with $10 \%$ foetal bovine serum and pen/ strep $(100 \mathrm{U} / \mathrm{ml}$ penicillin and $100 \mathrm{U} / \mathrm{ml}$ streptomycin). The cells were grown at $37^{\circ} \mathrm{C}$ in an incubator with a humidified atmosphere of $5 \% \mathrm{CO}_{2}$ until confluency was reached. Human normal bronchial epithelial cells $16 \mathrm{HBE}$ were kindly provided by the tumor Cell Library of the Chinese Academy of Medical Sciences.

\section{Patients and tissue procurement}

57 patients with primary lung cancer who underwent surgical resection at the Department of Thoracic Surgery of the Second Affiliated Hospital of Xi'an Jiaotong University, between June 2006 and June 2011, without pre-operative chemotherapy and/or radiation therapy, were enrolled in this study. 19 cases of normal lung tissues were benign lung lesions or at least $5 \mathrm{~cm}$ distant from the cancer site. The collections of lung cancer were mainly NSCLC (32 adenocarcinomas, 19 squamous carcinomas, 2 adenosquamous carcinoma, 1 carcinoid, 1 small cell lung cancer (SCLC), 1 pulmonary metastatic tumor from the oesophagus and 1 pulmonary metastatic tumor from the cervix). Patients' characteristics, such as gender, age, pathological pattern, lymph node invasion and Union for International Cancer Control (UICC) stage, are summarised in Table 1. The tissue procurement protocol used in this study was approved by the Human Research Committee of Xi'an Jiaotong University, and a written informed consent was obtained from each patient. All of the fresh tumor specimens and normal lung tissues were collected 
Table 1 Correlation between clinicopathological characteristics and Rab GDI $\beta$ expression

\begin{tabular}{|c|c|c|c|c|c|}
\hline Variables & Patients [n(\%)] & Positive & Negative & Positive rate (\%) & $\mathbf{P}$ \\
\hline \multicolumn{6}{|l|}{ Age } \\
\hline$\geq 65$ & 31 & 8 & 23 & 25.8 & \multirow[t]{2}{*}{0.740} \\
\hline$<65$ & 20 & 6 & 14 & 30.0 & \\
\hline \multicolumn{6}{|l|}{ Gender } \\
\hline Male & 27 & 7 & 20 & 25.9 & \multirow[t]{2}{*}{0.791} \\
\hline Female & 24 & 7 & 17 & 29.2 & \\
\hline \multicolumn{6}{|l|}{ Tumor size $(\mathrm{cm})$} \\
\hline$\geq 3.5$ & 26 & 7 & 19 & 26.9 & \multirow[t]{2}{*}{0.920} \\
\hline$<3.5$ & 25 & 7 & 18 & 28.0 & \\
\hline \multicolumn{6}{|l|}{ Histology } \\
\hline Adenocarcinoma & 32 & 9 & 23 & 28.1 & \multirow[t]{2}{*}{0.889} \\
\hline Squamous carcinomas carcinomas & 19 & 5 & 14 & 26.3 & \\
\hline \multicolumn{6}{|l|}{ Differentiation } \\
\hline G1-G2 & 30 & 8 & 22 & 26.7 & \multirow[t]{2}{*}{0.888} \\
\hline G3 & 21 & 6 & 15 & 28.6 & \\
\hline \multicolumn{6}{|l|}{ Lymph node metastasis } \\
\hline Node-positive & 29 & 7 & 22 & 24.1 & \multirow[t]{2}{*}{0.543} \\
\hline Node-negative & 22 & 7 & 15 & 31.8 & \\
\hline \multicolumn{6}{|l|}{ Distant metastasis } \\
\hline Yes & 4 & 2 & 2 & 50.0 & \multirow[t]{2}{*}{$0.300^{*}$} \\
\hline No & 47 & 12 & 35 & 25.5 & \\
\hline \multicolumn{6}{|l|}{ TNM stage } \\
\hline $\mid \sim \|$ & 24 & 7 & 17 & 29.2 & \multirow[t]{2}{*}{0.796} \\
\hline $\mathrm{III} \sim \mathrm{IV}$ & 27 & 7 & 20 & 25.9 & \\
\hline
\end{tabular}

${ }^{*}$ Fisher's exact test was used.

in the operating room, snap frozen in liquid nitrogen and stored at $-80^{\circ} \mathrm{C}$ until analysis.

\section{Primary reagent}

RPMI 1640 and foetal bovine serum were purchased from Hyclone (USA). RNAfast200 and RevertAid ${ }^{\mathrm{TM}}$ first-strand cDNA synthesis kit were separately obtained from Feijie Biotechnology Company (Shanghai, China) and Fermentas (USA). Rabbit polyclonal antibody against Rab GDI $\beta$ was purchased from ProteinTech (USA).

\section{RT-PCR}

Total RNA was extracted from cultured cells with RNAfast200 according to the manufacturer's instructions. A total of $1 \mu \mathrm{g}$ of RNA was used for reverse transcription; cDNA was generated and used as a template for RT-PCR analysis. RT-PCR was then performed using the RevertAid ${ }^{\mathrm{TM}}$ first-strand cDNA synthesis kit. PCR conditions for all of the reactions were as follows: $\operatorname{Rab} \mathrm{GDI} \beta, 94^{\circ} \mathrm{C}$ for $3 \mathrm{~min}, 94^{\circ} \mathrm{C}$ for $30 \mathrm{~s}, 50^{\circ} \mathrm{C}$ for $30 \mathrm{~s}$ and $72^{\circ} \mathrm{C}$ for $1 \mathrm{~min}$ (30 cycles) and $72^{\circ} \mathrm{C}$ for $5 \mathrm{~min}$; and $\beta$-actin, $94^{\circ} \mathrm{C}$ for $3 \mathrm{~min}, 94^{\circ} \mathrm{C}$ for $30 \mathrm{~s}, 58^{\circ} \mathrm{C}$ for $30 \mathrm{~s}$ and $72^{\circ} \mathrm{C}$ for $1 \mathrm{~min}$ (30 cycles) and $72^{\circ} \mathrm{C}$ for $5 \mathrm{~min}$. Gel images were collected by applying conventional electrophoresis on the PCR product. The expression levels of Rab GDI $\beta$ in A549 and 16HBE cell lines were evaluated using Image 1.44 software and under the reference of $\beta$-actin. Each experiment above-mentioned was performed in triplicate.

\section{Immunohistochemistry}

IHC staining was conducted according to standard streptavidin-perosidase (SP) methods. In brief, the tissue specimens were fixed in neutral buffered formalin and then embedded in paraffin wax. Tissue sections (thickness $=4 \mu \mathrm{m}$ ) were dewaxed, rehydrated, subjected to heat-induced antigen retrieval and blocked with normal goat serum for $15 \mathrm{~min}$. The slides were incubated with rabbit polyclonal antibody against Rab GDI $\beta$ at $4^{\circ} \mathrm{C}$ overnight, rinsed with phosphate buffered saline (PBS) and incubated with horseradish peroxidase-labelled secondary antibody. Rab GDI $\beta$ localisation was revealed using 3,3 $\square$ diaminobenzidine (DAB) as a chromogen. Negative control experiment was performed by replacing the primary antibody 


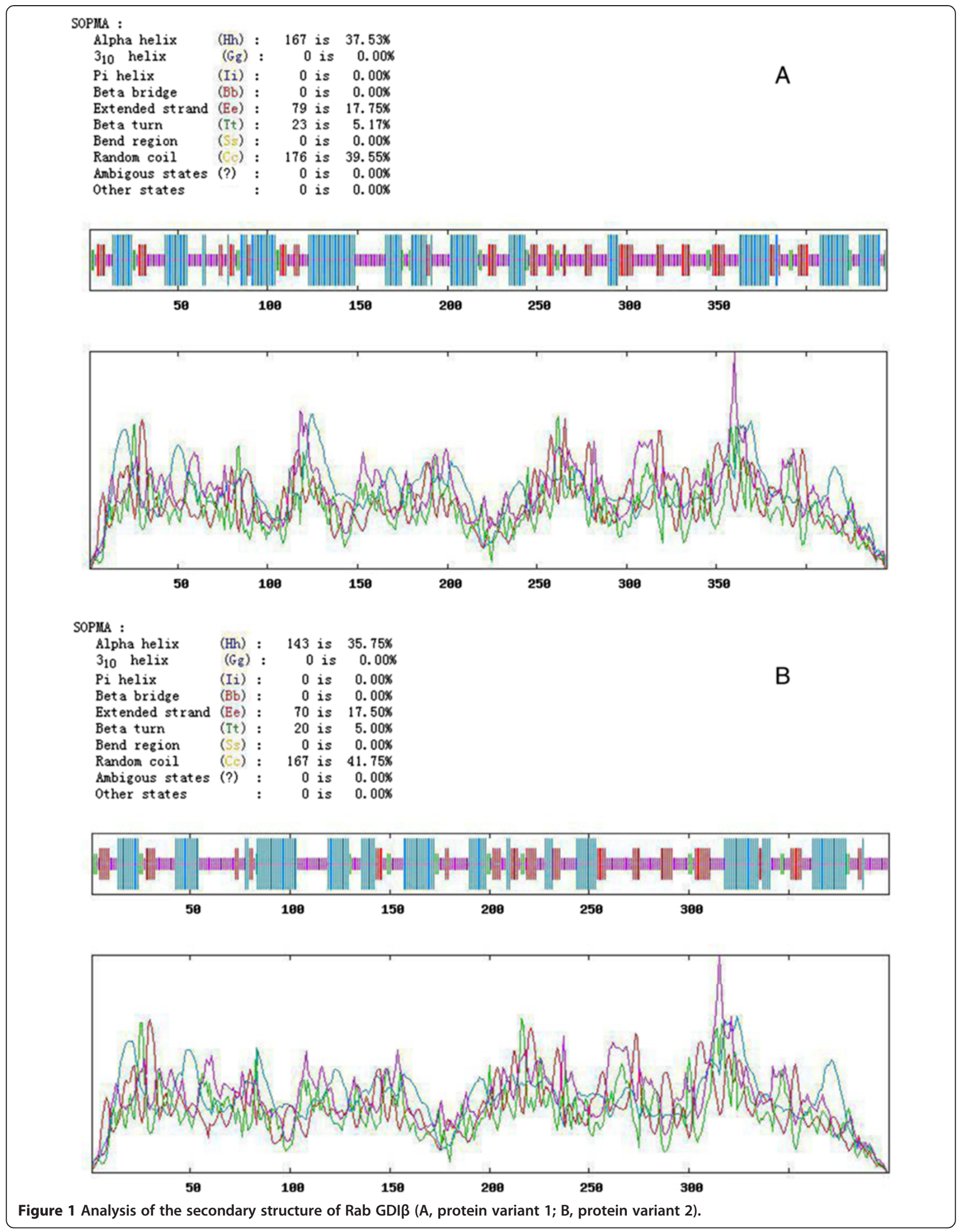


with PBS. The IHC staining levels of Rab GDI $\beta$ were assessed using a semi-quantitative staining index method [25]. The percentage of positive cells was assessed quantitatively and scored as follows: $0,<5 \%$ of the total counted cells were stained; $1,5 \%$ to $24 \%$ of the total counted cells were stained; $2,25 \%$ to $50 \%$ of the total counted cells were stained; and 3, $>50 \%$ of the total counted cells were stained. Intensity was graded as follows: 0 , no signal; 1 , weak; 2, moderate; and 3 , strong staining. A staining index ranging from 0 to 6 was generated by multiplying the percentage of positive cells and staining intensity of each sample. The total staining score was also graded as negative (-, score 0 ), weak (+, score 1 to 2$)$, moderate (++, score 3 to 4 ), or strong (+++, score 5 to 6). "-" was defined as negative expression, and ",,++++++ " were defined as positive. All of the slides were examined and scored independently by two pathologists who were blinded from the patient data.

\section{Statistical analysis}

The associations between IHC staining and clinicopathological factors were examined by $\chi^{2}$ test and Fisher's exact test. Statistical analysis was performed using the Statistical Package for the Social Sciences (SPSS) 19.0 software, and $\mathrm{P}<0.05$ was considered statistically significant.

\section{Results}

\section{Biological characteristics of Rab GDI $\beta$}

Rab GDI $\beta$ gene is located at chromosome 10p15 and measures a total length of $48327 \mathrm{bp}$. The mRNA of human Rab GDI $\beta$ exhibits two transcript variants. Transcript variant 1 is 2441 bp long; the initiation codon of the gene is ATG and the termination codon is TAA. The open reading frame of this variant ranges from $292 \mathrm{bp}$ to $1629 \mathrm{bp}$. Furthermore, transcript variant 1 contains 11 exons and 10 introns. Transcript variant 2 is $2306 \mathrm{bp}$ long. The initiation codon of the gene is ATG and the termination codon is TAA. The open reading frame of this variant ranges from $292 \mathrm{bp}$ to $1494 \mathrm{bp}$. Transcript variant 2 also contains 10 exons and 9 introns. A high degree of genetic homology is observed in human, gibbon, wren and macaque. For instance, transcript variant 1 is composed of 445 amino acids with a relative molecular mass of approximately 50663.2D; the theoretical isoelectric point and the half-life of this variant are 6.10 and $30 \mathrm{~h}$, respectively. Transcript variant 2 is composed of 400 amino acids with a relative molecular mass of approximately 45619.4D; the theoretical isoelectric point and the half-life of this variant are 5.91 and $30 \mathrm{~h}$. The common structural elements of these two proteins are mainly $\alpha$-helix, random coil, $\beta$-turn and extended strand (Figure 1). Furthermore, three and four transmembrane domains can be found in the entire polypeptide chain of protein variants 1 and 2, respectively. Both variants are
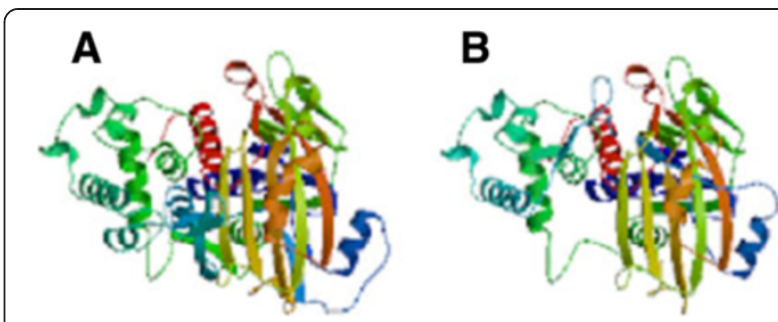

Figure 2 Prediction of the 3D structure of Rab GDI $\beta$ ( $A$, protein variant 1 ; B, protein variant 2 ).

hydrophilic and soluble proteins. One and two GDI activity regions are also found in protein variants 1 and 2, respectively. The subcellular localisation of protein variant 1 was analysed and revealed that this protein may be present in the following organelles: $39.1 \%$ in the cytoplasm; $17.4 \%$ in the mitochondria; $17.4 \%$ in the nucleus; $13.0 \%$ in the endoplasmic reticulum; $4.3 \%$ in the secretory vesicles; $4.3 \%$ in the Golgi apparatus; and $4.3 \%$ in the peroxisome. Likewise, the subcellular localisation of protein variant 2 was analysed and revealed that this protein may be present in the following organelles: $39.1 \%$ in the cytoplasm; $21.7 \%$ in the nucleus; $17.4 \%$ in the mitochondria; $8.7 \%$ in the endoplasmic reticulum; $4.3 \%$ in the secretory vesicles; $4.3 \%$ in the Golgi apparatus; and $4.3 \%$ in the peroxisome. The 3D structure of Rab GDI $\beta$ protein was predicted using Swiss-MODEL Repository software (Figure 2). The network diagram of Rab GDI $\beta$ gene interaction was obtained using GeneMANIA software (Figure 3). The network diagram of Rab GDI $\beta$ protein interaction was constructed using STRING9.0 software and by imposing restrictions on the search conditions within 20 genes (Figure 4).

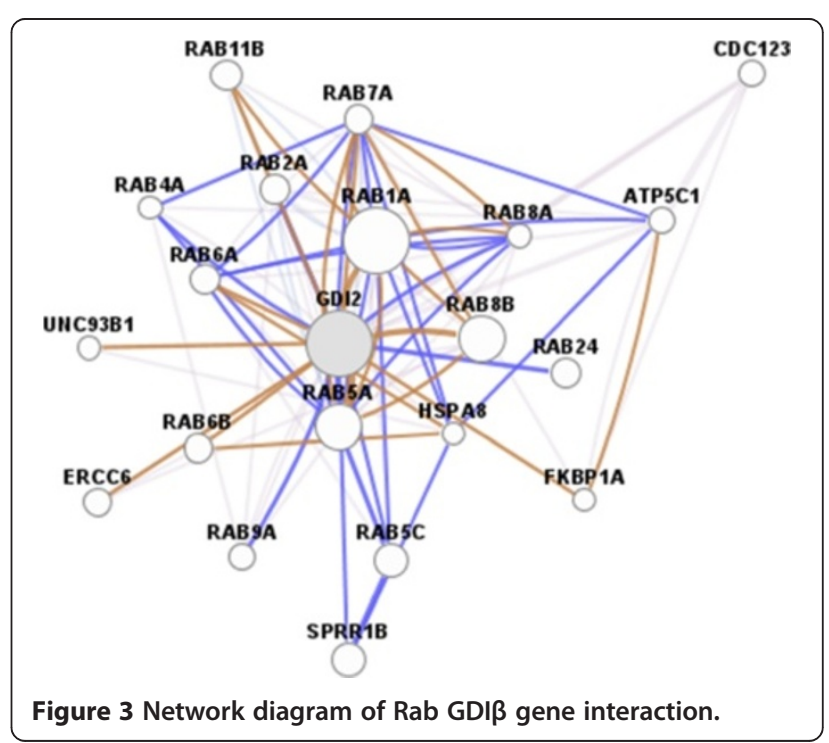




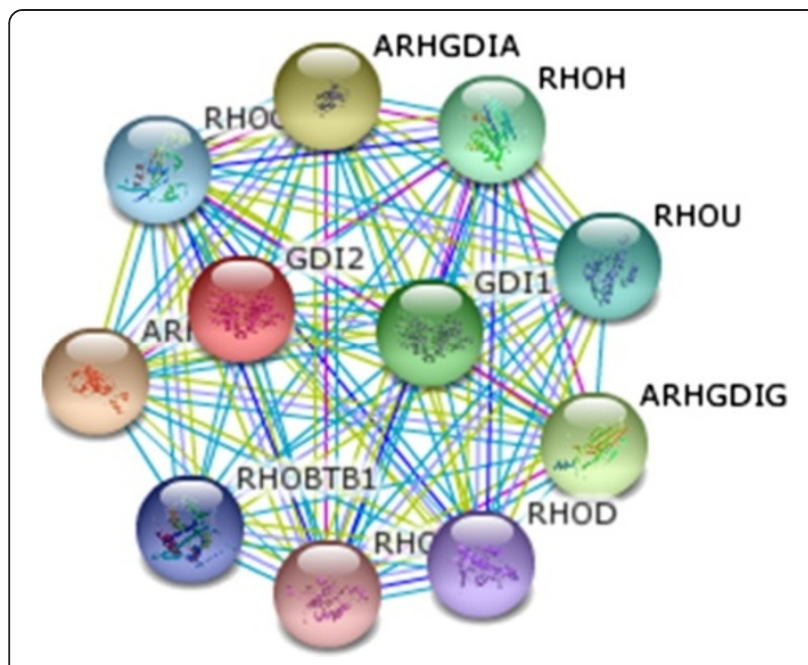

Figure 4 Network diagram of Rab GDI $\beta$ protein interaction.

mRNA levels of Rab GDI $\beta$ in A549 and 16HBE cell lines The electrophoresis results of the mRNA level of Rab GDI $\beta$ in A549 and 16HBE cell lines are shown in Figure 5. In particular, the mRNA level of Rab GDI $\beta$ in A549 was down-regulated. Using ImageJ 1.44 software and $\beta$-actin as a reference, we found that the relative expression level of Rab GDI $\beta$ in A549 was $0.25 \pm 0.07$.

\section{Protein expression of Rab GDI $\beta$ in tissue specimens}

Human lung cancer and normal lung tissue specimens were immunohistochemically stained. Our results showed that Rab GDI $\beta$ was expressed in the cell membrane and the cytoplasm, as indicated by brown granules (Figure 6). The IHC results also showed that 12 of 19 (63.2\%) normal lung samples were positively stained. Among the 57 lung cancer cases, only 18 showed positive expression, and the positive rate was only $31.6 \%$. The protein expression level of Rab GDI $\beta$ in adenocarcinoma was uniformly and significantly decreased $(\mathrm{P}=0.014)$ compared with normal samples. Similarly, $\chi^{2}$ test showed that the Pvalue between squamous carcinomas and normal tissues is 0.022 , meaning that the expressions in squamous carcinomas and normal tissues were also significantly different. Thus, Rab GDI $\beta$ expression was either absent or decreased in NSCLC.

\section{Associations between IHC staining and clinicopathological factors}

The Rab GDI $\beta$ protein expression in NSCLC tissues was not correlated with the patients' clinicopathological characteristics, such as age, gender, tumor size, pathological type, differentiation, lymph node metastasis, distant metastasis and tumor node metastasis (TNM) stage (Table 1). Adenosquamous carcinoma, carcinoid, SCLC and metastatic carcinoma were removed during the analysis because the included cases were very few.

\section{Discussion}

Bioinformatics is a new discipline that combines computer techniques and applied mathematics; bioinformatics is also a major core area of life science and natural science. In the current study, bioinformatics was applied to analyze the biological characteristics of Rab GDI $\beta$. Our result revealed high homology in humans and other species, suggesting that Rab GDI $\beta$ is conservative and implicated in in vivo processes. Rab GDI $\beta$ is primarily located in the cytoplasm and the organelles of membrane structures; this result

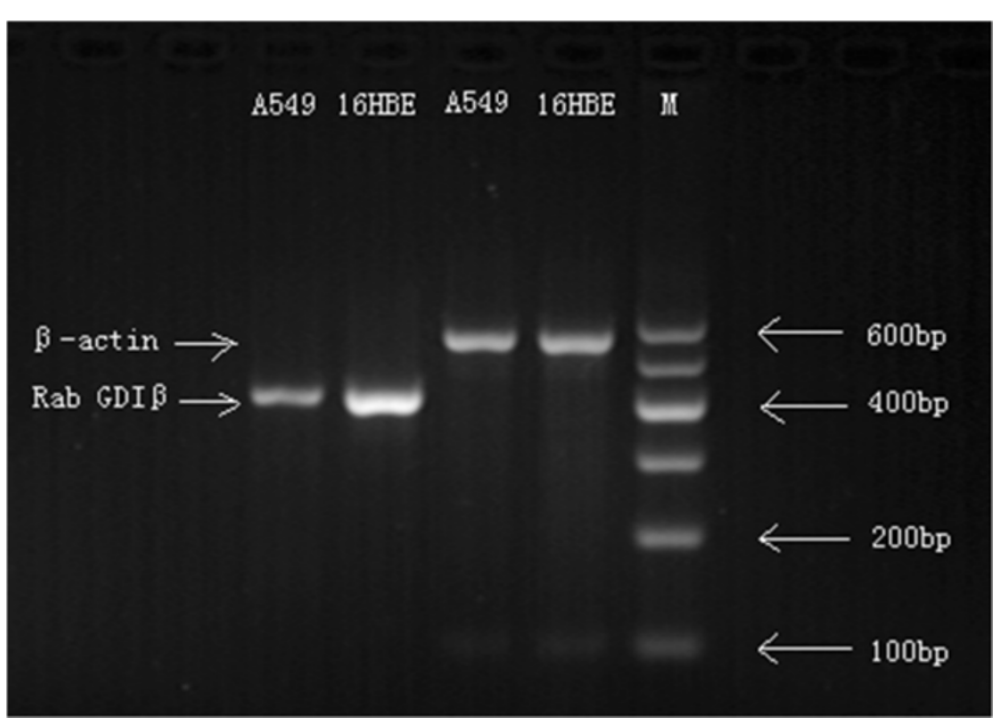

Figure 5 Electrophoresis of the Rab GDI $\beta$ gene PCR product in A549 and 16HBE cell lines (M: marker). 


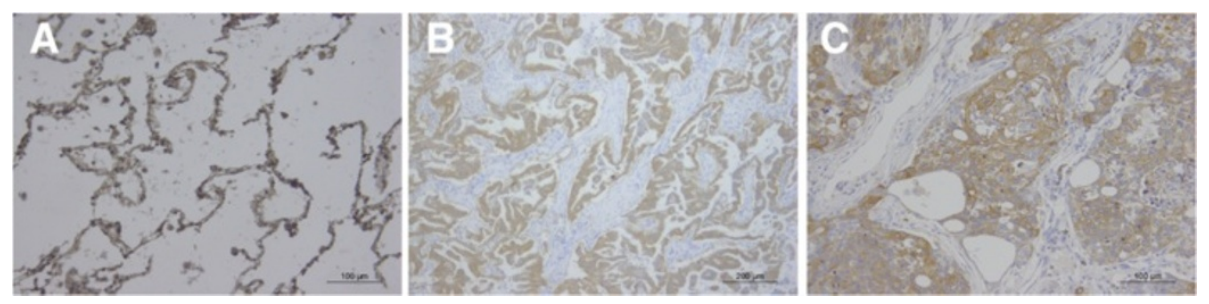

Figure 6 Expressions of Rab GDI $\beta$ in normal lung tissue (A, IHC, 200x), adenocarcinoma (B, IHC, 100x) and squamous carcinomas (C, IHC, 200x).

indeed showed that Rab GDI $\beta$ was involved in cellular vesicle transport. Gene and proteins interacting with Rab GDI $\beta$ are mainly family members of small G proteins. We could take these data to analyze the biological process and signal transduction pathways which Rab GDI $\beta$ may participate in. Thus, bioinformatics provided relevant information to elucidate the structure and function of Rab GDI $\beta$.

Rab GDI $\beta$ translocates prenylated Rab proteins from the cytosol to the membrane to form budding transport vesicles. Rab GDI $\beta$ also assists the subsequent retrieval of Rab proteins [26,27]; some of these proteins are tumorigenic or tumor suppressive [28]. Although the functions of Rab proteins in cancer progression have been studied intensively, information on Rab GDI $\beta$ action in this regard remains limited. Thus far, few expression studies have suggested that Rab GDI $\beta$ can activate or inhibit tumor progression. Sun et al. [29] conducted IHC and western blot analyzes, confirming that the increased level of GDI $\beta$ is associated with pancreatic carcinoma. In another study, proteomic analysis result has shown that GDI $\beta$ is identified as an upregulated protein with the effect of retinoic acids on the human breast cancer cell line MCF-7 [30]. By contrast, the expression levels of GDI $\beta$ in SKpac cells and chemo-resistant human ovarian cancer tissues are down-regulated [24].

In the current study, the mRNA concentrations of Rab GDI $\beta$ of lung adenocarcinoma cells and normal human bronchial epithelial cells were quantified by RT-PCR. This study is the first to report that the expression level of Rab GDI $\beta$ in lung adenocarcinoma cells was significantly lower than that in normal cells. Considering that mRNA expression may not accurately reflect protein level, we detected protein levels by IHC to verify this conclusion. The results showed that the protein level of Rab GDI $\beta$ varied with the corresponding mRNA level of Rab GDI $\beta$ in NSCLC and normal tissues; however, the protein level was not associated with patients' age, gender, tumor size, pathological type, differentiation, lymph node metastasis, distant metastasis and TNM stage. These findings suggested that the expression of Rab GDI $\beta$ in NSCLC was low, and this protein may be a candidate biomarker that could be used to diagnose NSCLC in early stages. This protein could also be used to provide new insights into the pathological mechanisms of tumor formation and development.

In a previous study, Rab GDI $\beta$ is considered as a gene that promotes differentiation and apoptosis but inhibits proliferation in various tumors. The current study suggested that Rab GDI $\beta$ was associated with human NSCLC. Rab GDI $\beta$ could be a potentially valuable prognostic indicator in patients with NSCLC. This information may also be used as reference by clinicians when they provide individualised therapy with optimal benefits for patients with NSCLC.

\section{Conclusion}

In summary, our data showed for the first time that the expression of Rab GDI $\beta$ decreased in human NSCLC. Rab GDI $\beta$ level was not correlated with patients' age, gender, tumor size, pathological type, differentiation, lymph node metastasis, distant metastasis and TNM stage. Rab GDI $\beta$ may be used as a novel marker in early-onset human NSCLC. However, the current study is only a preliminary report, and the number of samples in this research is limited; thus, further experiments should be conducted to confirm our conclusion. We recommend that a larger sample size should be used in future studies, and a cell excessive expression vector should be established to investigate the specific functions of Rab GDI $\beta$ in NSCLC.

\section{Abbreviation \\ Rab GDIß: Rab GDP dissociation inhibitor beta; NSCLC: non-small cell lung cancer; IHC: immunohistochemistry; 3D: Three-dimensional; SCLC: Small cell lung cancer; UICC: Union for International Cancer Control; SP: Streptavidin- perosidase; PBS: Phosphate buffered saline; TNM: Tumor node metastasis.}

\section{Competing interests}

The authors declare that they have no competing interests.

\section{Authors' contributions}

SYY and ZJM conceived and designed the study. CLG, MHJ and WL reviewed related literature and performed bioinformatics and statistical analyzes. YPZ, NF and YJZ conducted cell culture, RT-PCR and immunohistochemical studies. WL and $\mathrm{XM}$ extracted data and analyzed the relationship between immunostaining and clinicopathological factors. ZJM and MHJ drafted the manuscript. SYY reviewed and edited the manuscript. All of the authors have read and approved the final manuscript.

Acknowledgements

We thanks three anonymous reviewers for their insightful suggestions. 


\section{Author details}

'Department of Respiratory Medicine, the Second Affiliated Hospital of Xi'an Jiaotong University, Xi'an 710004, China. ${ }^{2}$ Department of Respiratory Medicine, People's Hospital of Tongchuan City, Tongchuan 727000, China.

Received: 6 March 2014 Accepted: 8 October 2014

Published online: 04 November 2014

\section{References}

1. Jemal A, Bray F, Center MM, Ferlay J, Ward E, Forman D: Global cancer statistics. CA Cancer J Clin 2011, 61(2):69-90.

2. Wen C, Dehnel T: People's Republic of China wrestles with lung cancer. Lancet Oncol 2011, 12(1):15.

3. Chen G, Gharib TG, Wang H, Huang CC, Kuick R, Thomas DG, Shedden KA, Misek DE, Taylor JM, Giordano TJ, Kardia SL, lannettoni MD, Yee J, Hogg PJ, Orringer MB, Hanash SM, Beer DG: Protein profiles associated with survival in lung adenocarcinoma. Proc Natl Acad Sci U S A 2003, 100(23):13537-13542.

4. Molina JR, Adjei AA, Jett JR: Advances in chemotherapy of non-small cell lung cancer. Chest 2006, 130(4):1211-1219.

5. Husain H, Rudin CM: ALK-targeted therapy for lung cancer: ready for prime time. Oncology 2011, 25(7):597-601.

6. Rom WN, Hay JG, Lee TC, Jiang Y, Tchou-Wong KM: Molecular and genetic aspects of lung cancer. Am J Respir Crit Care Med 2000 161(4 Pt 1):1355-1367

7. Geradts J, Fong KM, Zimmerman PV, Maynard R, Minna JD: Correlation of abnormal RB, p16ink4a, and p53 expression with $3 p$ loss of heterozygosity, other genetic abnormalities, and clinical features in 103 primary non-small cell lung cancers. Clin Cancer Res 1999, 5(4):791-800.

8. Sozzi G, Carney D: Molecular biology of lung cancer. Curr Opin Pulm Med 1998, 4(4):207-212

9. Motadi LR, Misso NL, Dlamini Z, Bhoola KD: Molecular genetics and mechanisms of apoptosis in carcinomas of the lung and pleura: therapeutic targets. Int Immunopharmacol 2007, 7(14):1934-1947.

10. Zhang W, Li YT, Yang SY, Li W, Ming ZJ, Zhang YP, Hou YL, Niu ZQ, Rong BX, Zhang XD, Liu XL: Differential mitochondrial proteome analysis of human lung adenocarcinoma and normal bronchial epithelium cell lines using quantitative mass spectrometry. Thoracic Cancer 2013, 10(7):374-379.

11. Sedlacek Z, Konecki DS, Korn B, Klauck SM, Poustka A: Evolutionary conservation and genomic organization of XAP-4, an Xq28 located gene coding for a human rab GDP- dissociation inhibitor (GDI). Mamm Genome 1994, 5(10):633-639.

12. Wu SK, Zeng K, Wilson IA, Balch WE: Structural insights into the function of the Rab GDI superfamily. Trends Biochem Sci 1996, 21(12):472-476.

13. Subramani D, Alahari SK: Integrin-mediated function of Rab GTPases in/cancer progression. Mol Cancer 2010, 9(1):312.

14. Nam KT, Lee HJ, Smith JJ, Lapierre LA, Kamath VP, Chen X, Aronow BJ, Yeatman TJ, Bhartur SG, Calhoun BC, Condie B, Manley NR, Beauchamp RD, Coffey RJ, Goldenring JR: Loss of Rab25 promotes the development of intestinal neoplasia in mice and is associated with human colorectal adenocarcinomas. J Clin Invest 2010, 120(3):840-849.

15. Liu SS, Chen XM, Zheng HX, Shi SL, Li Y: Knockdown of Rab5a expression decreases cancer cell motility and invasion through integrin-mediated signaling pathway. J Biomed Sci 2011, 18(1):58.

16. Barbarin A, Frade R: Procathepsin $L$ secretion, which triggers tumor progression, is regulated by Rab4a in human melanoma cells. Biochem $J$ 2011, 437(1):97-107.

17. Yang Q, Jie Z, Cao H, Greenlee AR, Yang C, Zou F, Jiang Y: Low-level expression of let-7a in gastric cancer and its involvement in tumorigenesis by targeting RAB40C. Carcinogenesis 2011, 32(5):713-722.

18. Hendrix A, Braems G, Bracke M, Seabra M, Gahl W, De Wever O, Westbroek W: The secretory small GTPase Rab27B as a marker for breast cancer progression. Oncotarget 2010, 1(4):304-308.

19. Yang PS, Yin PH, Tseng LM, Yang CH, Hsu CY, Lee MY, Horng CF, Chi CW: Rab5A is associated with axillary lymph node metastasis in breast cancer patients. Cancer Sci 2011, 102(12):2172-2178.

20. DerMardirossian C, Bokoch G: GDls: central regulatory molecules in Rho GTPase activation. Trends Cell Biol 2005, 2005(15):356-363.
21. Kwon K, Park E, Ryu D, Park B: D4-GDI is cleaved by caspase-3 during daunorubicin- induced apoptosis in HL-60 cells. Exp Mol Med 2002, 34:32-37.

22. Wang JW, Peng SY, Li JT, Wang Y, Zhang ZP, Cheng Y, Cheng DQ, Weng WH, Wu XS, Fei XZ, Quan ZW, Li JY, Li SG, Liu YB: Identification of metastasis-associated proteins involved in gallbladder carcinoma metastasis by proteomic analysis and functional exploration of chloride intracellular channel 1. Cancer Lett 2009, 281(1):71-81.

23. Bai Z, Ye Y, Liang B, Feng $X$, Zhang $H$, Zhang $Y$, Peng J, Shen D, Cui Z, Zhang Z, Wang S: Proteomics-based identification of a group of apoptosis-related proteins and biomarkers in gastric cancer. Int J Oncol 2011, 38(2):375-383.

24. Lee DH, Chung K, Song JA, Kim TH, Kang H, Huh JH, Jung SG, Ko JJ, An HJ: Proteomic identification of paclitaxel-resistance associated hnRNP A2 and GDI2 proteins in human ovarian cancer cells. J Proteome Res 2010 9(11):5668-5676

25. Fromowitz FB, Viola MV, Chao S, Oravez S, Mishriki Y, Finkel G, Grimson R, Lundy J: Ras p21 expression in the progression of breast cancer. Hum Pathol 1987, 18(12):1268-1275.

26. Pfeffer SR, Dirac-Svejstrup AB, Soldati T: Rab GDP dissociation inhibitor: putting rab GTPases in the right place. J Biol Chem 1995, 270(29):17057-17059.

27. Stenmark H, Olkkonen VM: The Rab GTPase family. Genome Biol 2001, 2:5 REVIEWS3007.

28. Chia W, Tang B: Emerging roles for Rab family GTPases in human cancer. Biochem Biophys Acta 2009, 1795(2):110-116.

29. Sun ZL, Zhu Y, Wang FQ, Chen R, Peng T, Fan ZN, Xu ZK, Miao Y: Serum proteomic- based analysis of pancreatic carcinoma for the identification of potential cancer biomarkers. Biochim Biophys Acta 2007, 774(6):764-771.

30. Kamal AHM, Han BS, Choi JS, Cho K, Kim SY, Kim WK, Lee SC, Bae KH: Proteomic analysis of the effect of retinoic acids on the human breast cancer cell line MCF-7. Mol Biol Rep 2014, 41(5):3499-3507.

doi:10.1186/s13000-014-0201-0

Cite this article as: Ming et al:: Bioinformatics analysis of Rab GDP dissociation inhibitor beta and its expression in non-small cell lung cancer. Diagnostic Pathology 2014 19:201.

\section{Submit your next manuscript to BioMed Central and take full advantage of:}

- Convenient online submission

- Thorough peer review

- No space constraints or color figure charges

- Immediate publication on acceptance

- Inclusion in PubMed, CAS, Scopus and Google Scholar

- Research which is freely available for redistribution 